\section{World researchers to take a closer look at Chernobyl}

\section{Munich}

FIve years after the nuclear disaster at Chernobyl, the world may finally get a closer look at the health effects of the radiation released by that accident.

Until recently, the Soviet Union has not been cooperative about releasing details of the calamity, but now, in conjunction with a programme of the World Health Organization (WHO), it will apparently open its doors to health researchers from the rest of the world.

On 6 May, the World Health Assembly, which is WHO's parliament, is expected to vote to lend WHO support to an international research programme to study the effects of Chernobyl. The programme, which began last year as a Soviet pilot project, will allow international researchers to gain unprecedented access to the Soviet population in order to carry out epidemiological and other studies and to track the effects of the accident on the incidence of cancer and other diseases.

A year ago, the Soviet Union began to set up a research centre at Obninsk, $100 \mathrm{~km}$ southwest of Moscow, to coordinate research on the effects of the accident. The Obninsk site was chosen because it already houses 15 research institutes of the Soviet aspects of radiation and nuclear science. At the same time, Soviet officials also began to set up satellite research centres nearer to Chernobyl itself in each of the three republics most strongly affected by the accident, the Ukraine, Byelorussia and the Russian Federation.

Earlier this year, Japan became the first WHO member state to volunteer assistance for the programme, pledging $\$ 20$ million to improve the facilities at Obninsk. The pledge came in response to a letter to the Japanese government written by Hiroshi Nakajima, the Japanese director-general of WHO, which is based in Geneva.

And now that the World Health Assembly has given its stamp of approval to the programme, WHO officials say that other members of the organization (which has 166 member states) are more likely to follow the Japanese lead and make donations. WHO itself has offered to play a coordinating role for international cooperation in the Chernobyl effects study programme, but it is not in a position to devote any of its own budget to the programme.

Long-term support for the programme is Academy of Sciences that deal with various an absolute necessity, WHO officials emphasize, because many of the cancer cases will not emerge for another 5-15 years or more.

The programme will attempt to track the progress of several types of cancer, the incidence of which is expected to rise because of exposure to radiation. The first cancers and other abnormalities to emerge in the next few years are expected to be leukaemias, followed by thyroid disorders after a 15 - to 20 -year latency period.

Another focus of the programme will be to assess the psychological and psychosocial effects of the disaster. Inspection teams from WHO and the Vienna-based International Atomic Energy Agency have reported that the largely rural local population blamed a variety of illnesses, especially among children, on radiation, even when this was clearly not the cause. The reported increase in children's illness, and in high blood pressure, anaemia and pulmonary disorders in the adult population are thought to be due more to feelings of depression and helplessness among the population than to the effects of radiation.

One potential stumbling-block for the programme is that it may not be able to determine how many cancers are due to the Chernobyl accident because Western experts say there were very few data available from the region before 1986 to use as a baseline for the study.

Steven Dickman

\title{
Five-year toll: 10,000 dead from Chernobyl?
}

\section{London}

How many people have really died because of radiation released by the Chernobyl accident? A Soviet scientist has reopened that question with his claim that the Soviet Union has covered up thousands of deaths, but other scientists remain sceptical.

Vladimir Chernousenko, a member of the clean-up team sent into the Chernobyl area after the accident, claims that between 7,000 and 10,000 of the 600,000 so-called 'liquidators' brought in to clean up after the accident have died because of exposure to radiation. The official death toll is 31 . The claim, made by Chernousenko in a British television documentary programme, broadcast by Thames Television, has been dismissed by the Soviet Ministry for Nuclear Power and Industry, and questioned by Western experts who have studied the consequences of the Chernobyl accident.

John Gittus of the British Nuclear Forum, who led the UK Atomic Energy Authority team studying the consequences of Chernobyl, says that non-acute health problems caused by radiation should be impossible to detect only five years after the accident. For solid cancers, studies of radiation-exposed populations, such as the Hiroshima and Naga- saki bomb survivors, show a ten-year latency period before excess cases appear. The UK Atomic Energy Authority estimates that Chemobyl will eventually cause 10,000 excess cancer deaths in the Soviet Union. This represents only 0.03 per cent of the natural Soviet cancer rate.

Evelyn Sokolowski, from the Swedish Nuclear Training and Safety Centre, says that the death toll given by Chernousenko is consistent with the natural mortality rate in the Soviet Union among a population of 600,000 averaging 29 years of age.

In an apparent attempt to discredit the cancer claims, Soviet authorities initially said that Chernousenko had no scientific credentials to discuss the effects of Chernobyl. In a biography distributed by the documentary's producers, Chernousenko had been described as the scientific director within the $30-\mathrm{km}$ exclusion zone that surrounds Chernobyl, and deputy chairman of the Ukrainian Academy of Sciences Commission responsible for rectifying the consequences of the accident. The Soviet authorities denied that Chernousenko was even a scientist.

Those authorities have now issued a second statement, quoting Victor Bar'jakhtar, chairman of the Ukrainian
Academy Commission on Chernobyl. This acknowledges that Chernousenko is a senior scientist at the Ukrainian Academy Institute of Theoretical Physics and a consultant to the Commission on Chernobyl, but says he is not the commission's vice-chairman.

Despite the general rejection of Chernousenko's fatality claims, some scientists who have visited the Chernobyl site are concerned about the safety of the Soviet scientists still working at Chernobylsome are even working inside the concrete 'sarcophagus' built to enclose the shattered reactor.

Brian East, head of health physics at the Scottish Universities' Research and Reactor Centre, says that Soviet physicists are working in primitive plastic oversuits in an area likely to be rich in plutonium, and seem to have no equipment to measure surface contamination with alpha particles; in the United Kingdom, workers entering areas where plutonium is being manipulated wear sealed suits with a positive pressure.

A more complete analysis of the health and environmental effects of Chernobyl will be released later this month by the International Atomic Energy Agency, which has co-ordinated a study involving a number of United Nations organizations.

Peter Aldhous 